\title{
Communication Strategies in Managing Conflict in Rural Communities in Semarang Regency
}

\author{
Nugraheni Arumsari ${ }^{1}$, Ngabiyanto ${ }^{2}$, Iwan Hardi Saputro ${ }^{3}$ \\ \{nugraheni.arum@mail.unnes.ac.id ${ }^{1}$ \}
}

Universitas Negeri Semarang, Indonesia ${ }^{1,2,3}$

\begin{abstract}
Conflict in social life is a natural and normal thing in society, because essentially each human being in the social community environment has different goals, interests, ideas, and perspectives. So when the interest involved is not only between individuals, but also between one group with another, that is the starting point for a conflict trigger. The interaction between leader (Lurah and village head in this case) and residents at the village and administrative village level can be said to be a fundamental process. Because, at this level the leader and those who are lead will meet to intensively interact and relate. At this lowest level, interaction and relationships, social control, policy, support, and program rejection will often occur. In the broader context of innovation, village leaders are also required to determine village policies aimed at community welfare. Community participation is needed for this policy, because without community participation and support, said policy will not run well and smoothly. This is usually where in a pluralistic society there is the possibility of a social rifts that cause friction. This will become a problem if a leader cannot manage the friction to prevent violence while at the same time producing a collective agreement, this is what triggered various conflicts over the years. This problem is what caused researchers to conduct research on "Communication strategies in managing conflict in rural communities in Semarang regency, namely in Kalisidi and Nyatnyono village". Theories used in this research are communication theory and conflict theory.Using a qualitative approach, the results of the study concluded that the village government, in this case the village officials of Kalisidi and Nyatnyono, resolved conflicts by using both groups and individual communication (interpersonal communication), the messages conveyed by village officials were constructive persuasive messages in the form of advices to minimize conflict occurrence. In addition, village officials also carried out activities involving village youth and the community such as gotong royong, the approach of the village community organization "LKMD" as an organizational groups' communication channel and as communication networks, making village budget information boards as a token of transparency, the use of social media as a means of public information and the making of billboards as a means to socialize the movement of tourism and education village.
\end{abstract}

Keywords: Communication, Conflict, Conflict Management. 


\section{Introduction}

Leadership at the village level is important to study, especially communication strategies form undertaken by the village head in encouraging development in the area, especially the participation of the community to realize an advanced and independent development. Leadership in this context does not only means the ability to lead, but also the capacity of leaders to interact with their citizens.

The interaction between leader (Lurah and village head in this case) and residents at the village and administrative village level can be said to be a fundamental process. Because, at this level the leader and those who are led will meet to intensively interact and relate. This is different from higher levels of government, for example at the sub-district level, district / city level, or even at the national level. At this lowest level, interaction and relationships, social control, policy, support, and program rejection will often occur. Thus, the synergy between the interests of villagers and village government policies can be realized. In addition, the synergy between villagers and village government is also important to anticipate making villages the object of village nationalization which results in state corporatism towards villages, as well as state desanization in the form of village so that policies adopted are in accordance with the wishes of the formal state by killing off local wisdom and aspirations (Mas'oed, 1994).

Therefore, at this level there will usually be more frequent conflicts, because a leader cannot carry out the program at his own will, for personal interests, or groups. These limits of power and authority are essentially not only due to the existence of legislative institutions at the village level, but also because villagers usually knowing their leaders well. By getting known, the leader is then always supervised and forced to be a good person, while at the same time having pro-public characteristics. Thus, institutional village government performance transparency and the village leader's personal communication are the main conditions in creating good synergy between villagers and village government, as well as other local actors.

\section{Research Problem}

This research is conducted to answer several important questions related to political communication strategies carried out by local actors (village level) in Semarang regency, in relation to conflict management in their region. The research problems proposed to frame this study is: What is the communication strategy in conflict management carried out by local actors (village level) to supervise conflict management in their area?

\section{Review of Related Literature}

This study is analyzed using two theories, namely the communication theory and the conflict theory. Communication theory is used to answer the question of how the communication strategies carried out by local actors in the community in their region. Whereas conflict theory is used to map the types and causes of conflict, also how local actors manage conflicts with the villagers. The following explanation is related to these two theories. 


\subsection{Communication Theory}

D. Lawrence Kincaid and Wilbur Schramm in Arifin, Anwar (2008) explained that communication is the process of sharing or using information together and the linkages between participants in the information process. In addition, communication can also be interpreted as a process of contacting or establishing relationships using language, gestures, bodies, systems, signals, codes and others. Another formulation beside the ones above was stated by William Albig in Cangara (2008) in his book Public Opinion, he wrote that communication is the process of passing meaningful symbols between individuals.

To explain the notion of communication, some experts provide an explanation in the form of communication definition so that it can be understood and comprehended, therefore the authors propose several experts' notion of communication. According to the Code in Sasa Djuarsa Sendjaja (1993) [1], "Communication is a process that makes something which was originally owned by someone (one's monopoly) to be owned by two or more people".

\subsection{Group Communication}

Group is a gathering of people consisting of two or three or more people who have an intensive relationship between them, especially the primary group, the intensity of the relationship between them is the main requirement made by people in the group. So, group communication is communication that takes place between several gathered people.

Communication Strategies

There are four objectives in the communication strategy as follows (Effendy: 2005): (1) To Secure Understanding, namely, to ensure that an understanding occurs in communication. (2) To Establish Acceptance, namely how the acceptance is well received. (3) To Motivate Action, namely, to actively motivate communication, and (4) To Goals Which Communicators Sought to Achieve, namely, how to achieve goals aspired by the communicator of the communication process.

Strategy also has a dual function as explained by Effendy, namely: (1) Propagate communication messages that are informative, persuasive, and instructive in a systematical way to the target to obtain optimal results. (2) Bridging the "cultural gap", namely the conditions that occur due to the ease of obtaining and operating such a powerful media, which if left unchecked will damage the built values.

\subsection{Conflict Theory}

Humans in carrying out their life activities cannot avoid conflict. This is because conflict is one of the essences of human life and development which has various characteristics. Differences in sex, social and economic strata, legal system, nation, ethnicity, religion, beliefs, political flow, also cultural and life goals determine the emergence of conflict in society, so conflict will always occur in the past, present, and will definitely occur in the future [2].

Furthermore Wirawan (2010) [2] explains that the quantity and quality of conflicts that occur in Indonesia in the future tends to increase. The tendency to increase conflict's quantity and quality is due to the development of civil society. Civil society creates various non-governmental 
organizations (NGOs) that seek to defend victims of human rights violations by government and other community members. (Wirawan, Conflict doesn't always have to be avoided because it doesn't necessarily have a negative impact on the involved parties. Conflicts that are mild and can be properly controlled will have a positive impact and benefits those involved and also to the agency or organization. Conflict is a learning opportunity for the parties involved to make a good resolution.)

Conflict according to the view of Fajar (2016) arises because of differences in interests, goals, values, and forms of communication failure that ultimately carry certain implications including changes in social interaction. Conflict brings major changes to social balance and brings new equilibrium to replace pre-existing balances. This means that conflict can bring social change.

Hunt and Metcalf (1996) [3] divide conflict into two types, namely intrapersonal and interpersonal conflict. Intrapersonal conflict is a conflict that occurs within oneself, for example when the beliefs held by an individual contradicts the societal cultural values, or when their desires are not in accordance with their abilities. Intrapersonal conflict is more individual, and if it is not overcome properly it will affect the psychological health or mental hygiene of the individual concerned. Meanwhile, interpersonal conflict is a conflict that occurs between individuals. This conflict usually occurs in social environments, such as in families, peer groups, schools, communities, and countries. This conflict can also be a conflict between individuals and groups, both inside a group (intragroup conflict) and in the form of conflict between groups (intergroup conflict).

Definition of conflict is an inseparable part of social life in the community and is often used as a prerequisite for social change. But the conflict will lead to mutual agreement. Therefore, conflict implies the definition of clashes such as differences of opinion, competition, and conflict between individuals, clash between groups, individual conflicts with groups, as well as between individuals or groups with the government [4].

\subsection{Communication-based Conflict and Resolution}

Regarding conflict management strategies, Rahim [5] mentions that there are several stages that must be carried out: intrapersonal, interpersonal, intragroup, and intergroup. This shows that in managing conflict, action is taken not only on the conflict or its causes, but also there has to be an improvement from within the perpetrators of the conflict itself. The conflict process is not something instant, nor is the solution that must be taken.

An interesting thing was stated by Hasenclever and Rittberger [6], that in some conditions, the existence of religion is also able to be a facilitator in conflict resolution. So far, what we often find is that religion triggers conflict, whereas religious dialogues can actually moderate conflicts and crises. This is due to the intense religious dialogue which is able to promote openness and minimize the prejudice of one individual with another, and between groups [7].

Forsyth [8] divides the types of methods for carrying out conflict resolution that can change members of disputing groups into a peaceful and concise settlement. Methods include the following.

1. Commitment $\rightarrow$ Negotiation Method

Conflicts can arise when members in the masses are convinced of their position and there is no desire to succumb to each other, but conflicts can be mitigated when group members decide to negotiate to reach an agreement that can benefit all parties. 


\section{Misperception $\rightarrow$ Understanding}

Conflicts often occur due to misunderstanding. Therefore, there needs to be active communication to reduce the misunderstanding by means of discussion. Communication can open up opportunities for group members to trust each other, but on the other hand can also backfire because it can cause resentment or dislike for other members.

3. Strong Tactics $\rightarrow$ Cooperative Tactics

In dealing with conflicts, there are several ways that can be done by the conflicting group, among others by discussing the conflict, forcing members to accept the views of other groups, and relying on cooperation in finding appropriate solutions that can be accepted by all parties.

\section{Upward $\rightarrow$ Downward Conflict Spirals}

This method is carried out by consistently collaborating for a long period of time so as to increase mutual trust.

5. Many $\rightarrow$ One

This method of resolving conflicts involves third party (neutral parties) who act as mediators in the conflict. The methods used by the third parties include: relieve frustration and hatred by giving opportunities to both parties to express their feelings. In addition, if the communication does not go smoothly, a third party can help to correct the problem.

\section{Anger $\rightarrow$ Composure}

This method is effective for controlling emotions by doing humor or jokes in groups. Humor can provide positive emotions and can reduce negative emotions such as anger.

From these various views, the analysis related to this research will answer the question of how conflict management is carried out by local actors, especially in overcoming conflicts that occur in their region due to communication with the community. The analysed conflict is a type of interpersonal conflict because it involves the community. In addition, this study also examined the conflict resolution methods carried out by local actors to resolve disputes with the community.

\section{Research Methods}

This research is a qualitative research. Creswell (2014: 179) [9] argues that qualitative research is flexible and changes in accordance with field conditions, so that the role of researchers is very dominant in determining the success of research conducted. The main characteristic of qualitative research is that the procedure depends on data in text and images form. This research is intended to describe and study the communication strategies of local actors in conflict management in rural communities in Semarang Regency. The research subjects were local actors (village heads) in Nyatnyono and Kalisidi Village. The characteristics of the two villages are the reason why this research was conducted. The villagers of Kalisidi and Nyatnyono Village are two villages in Semarang Regency that are experiencing progress, especially in the field of tourism.

\section{Findings}

The communication strategy undertaken by the village head is not only a means of interaction but also a measurement of success in leading the villagers, because every interaction carried out by the village head is what moves the community in the process of the village success and create a 
comfortable atmosphere, and the opposite occurs when the village head does not have a good communication strategy, a rejection can happen in the community.

The communication strategy developed by Kalisidi Village is different from another village. The village head can still be categorized as a young village head who has good self-capacity. As the village head is not arbitrary and arrogant, on the contrary the highlighted character is polite, smiling, willing to mingle with anyone, respects subordinates "respecting village officials", willing to mingle with people indiscriminately, and be creative.

Politeness and smiles are often shown to anyone who greets the village head, often he greets the people who pass by in front of him to show his care for the villager. Easy to mingle with anyone means that the village head doesn't choose and sort out people in the process of interacting but instead tries to interact with any group, he even makes an initiation to create a WhatsApp group for the villager so that problems can be quickly dealt with by him.

The communication strategies undertaken by the village head has many types, one of which can be described in the following table:

Tabel 1. Communication Table for The Village Head

\begin{tabular}{|c|c|}
\hline Kalidisi Village & Nyatnyono Village \\
\hline $\begin{array}{l}\text { - } \begin{array}{l}\text { Direct approach to the community } \\
\text { (interpersonal communication channels) }\end{array} \\
\text { Bringing Village Community Institutions } \\
\text { closer (organizational group } \\
\text { communication channels and } \\
\text { communication networks) } \\
\text { - Making a Village Budget Information } \\
\text { Board as a Token of Transparency } \\
\text { - Using social media (Facebook, Twitter, } \\
\text { Website, Instagram, Youtube) Making } \\
\text { social media as a means of Public } \\
\text { Information } \\
\text { Making Billboards as a media to socialize } \\
\text { tourism and education village movements }\end{array}$ & 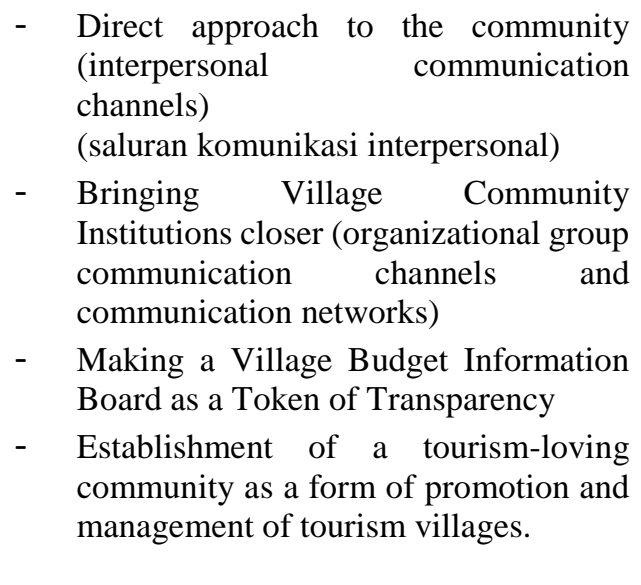 \\
\hline
\end{tabular}

Source: Interview

This form of communications can be used to minimize conflicts that usually occur in villages, one of which is conflicts that usually occur in villages when there are village meetings or more often referred to as village meetings in determining facilities and infrastructures in Kalisidi Village which is a substantive conflict.

In accordance with the results of research conducted in the Kalisidi Village, which is currently led by Dimas Prayitno Putro, in his young age, sometimes he still encounters several obstacles in leading the village deliberations. He said that the community still considered that he was not being fair in building and providing village facilities and infrastructure, he gave an example of the use of 
natural attractions in the Kalisidi Village that is Benowo and Lawe Falls. The utilization of natural resources cannot run smoothly without any obstacles. This happened when the Lawe - Benowo Kalisidi waterfall would become a tourist place with a better and more professional management, there are some opposing people because it is feared that the increasing number of visitors will cause damage to the waterfall. This was of course not an easy thing to convince villagers that by opening the Lawe - Benowo Kalisidi waterfall as a tourist attraction would certainly increase the village income.

Because of this, there are some villagers who are in the pros and cons with the opening of Benowo Kalisidi waterfall as a commercial tourist attraction because they believed it would damage the natural habitat. Also, the village head is not considered as doing equitably in facilities and infrastructure, especially in the road asphalting. So that the village community held a demonstration aimed at the village head, this made the situation quite stormy and heated up. They demanded the village head to fulfill the rights that they considered had not yet been fully obtained, one of which was the completion of the road asphalting project in one of the hamlets in Kalisidi, which was now badly damaged and unfit for passage, also the damaged road made the area accident-prone, even more so at night it is very dark because there were only a few street lights illuminating the village border, the rest of the lighting came from residents' houses, this was what makes the hamlet prone to criminal acts.

To overcome this conflict, a communication strategy is needed to resolve conflicts, including mediation. Mediation was done by compromise, where the mediator team tried to find a middle way by reducing the demands to the village head, the beginning of mediation by compromising was done by holding a village meeting attended by the village head and village officials, all $R W$ and $R T$ heads in Kalisidi Village, Hamlet Informant (Representative of Hamlet), Kalisidi Village Community and several other village residents.

Then in the meeting the mediator consisting of the village officials, hamlet representatives invited one of the residents from one of the $R W \mathrm{~s}$ in the village to express what the problem was and the demands of the villagers, which were more or less like this:

a. Transparency in the use of village funds

b. Equitable allocation of natural resources of the Kalisidi Village community.

In accordance with conflict mapping, the most ideal style of conflict resolution was carried out in mediation and compromise between the village head and all residents of Kalisidi Village, this was done to resolve conflicts and minimize clashes between village heads and residents involved.

For this reason, the best communication strategy was that there must be socialization about the village program and of course the use or allocation of village funds related to facilities and infrastructure as well as intense mediation with the village community while still prioritizing their customs, culture, social, and economic conditions. With an intense mediation with the community that promotes good interpersonal communication between leaders and villagers so as to minimize the occurrence of prolonged and ongoing conflict. This could occur due to lack of closeness (miscommunication) between policy makers or government and the community. So there should always be a more intense dialogue space, because so far it is still minimal with these moral values.

\section{Conclusion}


The communication strategy undertaken by the village head as a means of supporting existing development innovations in the village is considered very important. Interpersonal communication is the choice most often used by village heads in daily communication, besides that social media is also considered to be an effective means of communication in the current era. Interpersonal communication and group communication as a form of transparency are also felt as a success measurement of the development innovations that exist in the village and also to resolve conflicts that occur in the village.

The village head is demanded to be able to behave and act in accordance with the existing culture in the community so that the beliefs, norms, and networks that have been built in the community

will be stronger, and the impact will have direct implications in minimizing the occurrence of conflict in the village.

\section{References}

[1] D. S. Sendjaja, Pengantar Komunikasi. Jakarta: Universitas Terbuka, 1996.

[2] Wirawan, Konflik dan Manajemen Konflik: Teori, Aplikasi dan Penelitian. Jakarta: Salemba Humanika, 2010.

[3] L. Hunt, M.P. and Metcalf, Ratio and inquiry on Society's Closed Areas, in Educating The Democratic Mind (W. Parker). New York: State University of New York Press, 1996.

[4] R. Surbakti, Memahami Ilmu Politik. Jakarta: Grasindo, 1992.

[5] M. A. Rahim, “A strategy for managing conflict in complex organizations," Hum. Relations, vol. 38, no. 1, pp. 81-89, 1985.

[6] V. Hasenclever, A., \& Rittberger, "Does religion make a difference? Theoretical approaches to the impact of faith on political conflict," Millennium, vol. 29, no. 3, pp. 641-674, 2000.

[7] R. Brubaker, "Religious dimensions of political conflict and violence," Sociol. Theory, vol. 33, no. 1, pp. 1-19, 2015.

[8] D. R. Forsyth, An Introduction To Group Dynamics. California: Cole Publishing Company, 1983.

[9] J. W. Creswell, Research Design Pendekatan Kualitatif, Kuantitatif, dan Mixedr. Yogyakarta: Pustaka Pelajar, 2014. 